Mediterranean Journal of Humanities mjh.akdeniz.edu.tr

IV/1, 2014, 171-179

\title{
On the History of Religions in Philadelphia in Lydia until the end of Late Antiquity
}

\author{
Geç Antik Çă̆g'ın Sonuna Kadar Lydia'daki Philadelphia'da Dinler Tarihi
}

\section{Orçun ERDOĞAN*}

\begin{abstract}
Since both the archaeological and written evidence are incomplete, a detailed history of the religions, particularly of the Jews in Philadelphia cannot be evaluated sufficiently for the present. Philadelphia is generally presented in the context of the Seven Churches of John or the Seven Letters of Ignatius in studies concerning the history of religions. Similarly the city usually remains unmentioned in collective regional studies on Jews and Pagans. Until and during Late Antiquity, Philadelphia became one of the cities where a gradual transformation of religions was experienced. In this study, a summarized history of the religions of Philadelphia and in its surroundings is given chronologically rather than theologically as well as their fate to the end of Late Antiquity.
\end{abstract}

Keywords: Alaşehir, Late Antiquity, Pagans, Jews, Christians, Synagogue, Montanism, Seven Churches

Öz: Arkeolojik verilerin ve yazılı kaynakların yetersizliğinden dolayı Philadelphia'nın dinler tarihi hakkındaki bilgilerimiz oldukça kısıtlıdır. Kentle ilgili yapılan dinler tarihi çalışmaları genellikle Ioannes'in Yedi Kilise ya da Ignatius'un Yedi Mektupu ile ilgili Hıristiyan teolojik çalışmaların bir bölümü olarak sunulmuştur. Benzer şekilde Yahudiler ve Paganlar üzerine yapılan kollektif çalışmalar içerisinde incelenen kentler arasında Philadelphia çoğunlukla eksik kalmıştır. Geç Antik Çağ boyunca Anadolu'da dinler tarihi açısından birçok değişimin yaşandığı yerleşimlerden biri Philadelphia'dır. Bu çalışmada, mevcut veriler ışığında kent ve çevresinde varlık gösteren dinler-teolojik açıdan öte kronolojik olarak- kısaca ele alınarak, bu dinlerin Geç Antik Çağ sonundaki akıbetleri ortaya koyulmaya çalışılmıştır.

Anahtar sözcükler: Alaşehir, Geç Antik Çağ, Paganlar, Yahudiler, Hıristiyanlar, Sinagog, Montanizm, Yedi Kilise

Alaşehir, known as Philadelphia in Antiquity and the Middle Ages is located some fortyfive kilometers southeast of Sardis. Today it is a town and district of Manisa Province in the Aegean region of Turkey. Our knowledge of the earliest period of the settlement comes from excavations and surveys. According to recent research, some hilltop settlements dating from the Neolithic Age were found in the vicinity of Alaşehir (Akdeniz, 2011, 5-23). In addition, particularly the city centre, where Roman and Byzantine ruins can still be seen, indicates a later period, except for the Gavurtepe Mound where some early remains were found which may date to the early Bronze Age (Meriç, 1986, 261; Meriç, 1988, 157- 158).

The place where King Xerxes passed through in 481 B.C. was a Lydian city, Calletebus, and it is thought to have been in the same location as Philadelphia (Umar, 2001, 171-172). The city was founded in the period of Seleucus I (312-281 B.C.) or have completed its foundation by the

\footnotetext{
* Res. Assist., Department of Art History, Akdeniz University, Antalya, orcunerdogan@akdeniz.edu.tr
} 
reign of Attalus II Philadelphus (159-138 B.C.) (Onur, 2013, 37, fn. 105). Philadelphia was most probably a military colony since the coins from the $\mathrm{II}^{\text {nd }}$ century B.C. carry the image of a Macedonian shield (Thonemann, 2011, 174-175). In 133 B.C. Philadelphia was annexed by the Romans and gained importance from this period (Fig. 1.). Although it was damaged by an earthquake in 17 A.D. it was reconstructed with support from Tiberius.

To what extent Philadelphia was affected by the Gothic invasions remain obscure. When considered the incursions by the Goths in Lydia (Foss, 1976, 9; Mitchell, 1993a, 235-236) and the significance of the location of the city (Zos. IV. 30; see also, Ramsay, 1904, 395; Umar, 2001, 171-172), that Philadelphia has been under threat during the $\mathrm{III}^{\mathrm{rd}}$ and $\mathrm{IV}^{\text {th }}$ centuries A.D. can be suggested. This idea is plausible as the city walls were constructed or renovated in this period, similarly to those of many Anatolian cities, particularly neighbouring Sardis dated to the late $\mathrm{III}^{\text {rd }}$ or IV $^{\text {th }}$ century A.D. (Zanten, 1975, 36).

In the $\mathrm{VI}^{\text {th }}$ century Philadelphia had an important position, as the pursuers of Proklos called it little Athens because of its festivals and temples (Foss, 1991, 1648), Ioannes Lydos mentioned the suffering of Philadelphia under the praetorian prefect John the Cappadocian (531-541). According to the account of Lydos, Maxilloplumacius, the vicar of Asia, came to Philadelphia and released the tax collectors on the country, so Philadelphia was stripped of its money and the people were left without resources to recover (Foss, 1976, 11).

\section{Pagans}

The early evidence for cult traditions can poorly be traced due to the limited number of finds and remains uncovered in excavations at Gavurtepe. Here, some remains of megaron like structures were unearthed, one of which is said to be a palace of a ruler (Meriç, 1986, 261; 1992, 227-228; Meriç, 1993, 356). During excavations, a small number of marble objects, identified as idol and dated to the Early Bronze Age were found (Meriç, 1992, 228; 1993, 356). Despite the evidence of such megaron structures and finds of idols show no cult center was found, but they are suggestive of the early cult habits of the city.

Evidence from the Late Hellenistic Period informs us of the polytheistic background of the settlement. Some of the local cults, temples or sacred areas have been partly determined through epigraphic finds. Some gods and goddesses such as Zeus, Dionysos, Apollo and Artemis were the most depicted figures on both sides of the coins from Philadelphia during the $\mathrm{II}^{\text {nd }}$ and $\mathrm{I}^{\text {st }}$ century B.C. (Doğan, 2010, 5-17). An inscription on a boundary stone from the village of Badinca, about $3 \mathrm{~km}$. southeast of Philadelphia and dated to 279- 267 B.C. is significant, in that it indicates a sacred area dedicated to Apollo Toumoundus (Meriç-Nolle, 1985, 20-21; Malay, 1994, 54). Apollo was also depicted with the inscription "APXIEPEY $\Sigma$ ” (High Priest) on the reverse of some Philadelphian coins dating from the IId $^{\text {nd }}$ century B.C. (Doğan, 2010, 11). While both these data probably indicate an ongoing veneration of Apollo, similar archaeological evidence such as votive or honorary inscriptions connected with Dionysus, Artemis and some other local cults have been discovered (Blake, \& Edmons, 1982, 149; see in general Malay, 1994, 31-165).

While the influence of Hellenistic cults continued (for the depiction of a temple probably dedicated to Helios in Philadelphia see Doğan, 2010, 45; for the honorary inscription of the priest of Artemis see Malay, 1994, 39), during the Roman Empire, the existence of some other cults becomes visible, one of which is the Emperor Cult (for the prototypes see Baz, 1998, 2149). An inscription found in the village of Badinca (Southest of Philadelphia) records the city had a priest of Rome and Augustus as early as 27/26 B.C. (Malay, 1994, 33). In the years following 
the emergence of the Imperial Cult, some cities had the title "Neocorate" to celebrate the imperial festivals (Burrell, 2004, 396-397) and Philadelphia was also given the right to a neocorate (Neokoros - Temple warden) to celebrate a major imperial festival by the early years of III ${ }^{\text {rd }}$ century A.D. (Mitchell, 1993, 258; Doğan, 2010, 51). Philadelphia is known to have had the title Neokoros 6 or 7 times until the time of Trajan Decius (Burrell, 2004, 396-397; Doğan, 2010, 54).

There is some evidence that exemplify the veneration of local divinities (For example "Meter Matyene" from the $\mathrm{I}^{\text {st }}$ or $\mathrm{II}^{\text {nd }}$ century A.D., "Men ek Diodokou” from 173/4 A.D., "Theos Hosios Kai Dikaios" from 296/87 A.D. for the inscriptions see Malay, 1994, 58, 68, 72). Among them the most detailed information comes from the Cult of Meter (or Thea). The inscriptions shows that the goddess Meter Phileis was revered for help in health problems (for the inscriptions see Malay, 1985, 111-126; 1994, 59-65). All the inscriptions found in the sacred area of the Goddess, date from the II $^{\text {nd }}$ or III $^{\text {rd }}$ century A.D. except one dated to 299-308 A.D. which may indicate a period of cessation or decline in the cult.

\section{Jews}

In the Hellenistic and Roman eras there were Jewish communities living among the pagans in many parts of the world and when considered the region surrounding Philadelphia, a similar situation can be deduced from documents and inscriptions. From a document quoted by Josephus, the transportation of 2,000 Jews to Lydia and Phrygia is attested around the first quarter of the III $^{\text {rd }}$ century B.C. Evidence suggests that there were Jewish communities in a number of cities in Asia Minor in 139-8 B.C. (Trebilco, 1991, 5-7). Especially during the Imperial Period, the Roman authorities granted various privilages to different Jewish communities in Asia Minor. Some of these included the right to be organised as a community, to observe the Sabbath, and to build synagogues (Trebilco, 1991, 8-19).

Historical evidence for a Jewish community in Philadelphia is quite sparse, when compared to nearby cities to which some number of documents and inscriptions as well as synagogues associated with the Jews are known. In neighbouring Sardis a Jewish community probably existed as early as the $\mathrm{V}^{\text {th }}$ century B.C. and there was a synagogue between the late IId $^{\text {nd }}$ century and 270 A.D. with some remodelling in the $\mathrm{IV}^{\text {th }}$ and up to the early VII ${ }^{\text {th }}$ century A.D. (Foss, 1976, 41-42; Trebilco, 1991, 40-41). Similar evidence of synagogues and numerous Jewish inscriptions was found in Acmonia, Apamea and particularly Sardis indicating the Jewish population in the area surrounding Philadelphia (for the Jewish evidence in a regional perspective in the Hellenistic and Roman period see Trebilco, 1991, 37-103).

While there is lack of information for the pre-Roman period, two written sources presumably confirm the existence of Jewish communities in Philadelphia. The first is the Book of Revelation in the New Testament probably from the second half of the $\mathrm{I}^{\text {st }}$ century A.D. and secondly The Letter to the Philadelphians by Ignatius of Antioch from around the beginning of the II ${ }^{\text {nd }}$ century. The author of the Revelation speaks of the synagogue of Satan (Rev 3:9) in his Message to the Church in Philadelphia. Here the Synagogue is likely to be a metaphor rather than a building (see also Rev 2:9), however the controversy between the Jewish community (for those who are called Jews in the Revelation see Trebilco, 1991, 27) and Christians (Rev 3:8-10) indicates the presence of Jews in the city as early as the $I^{\text {st }}$ century A.D. Ignatius' stay at Philadelphia is significant for witnessing the atmosphere there. In The Letter to the Philadelphians, while he generally speaks of Christianity and heresy, he comments briefly on Judaism as well (Phld 6:1-2), probably referring to the Jewish Christians and the Gentile 
Christians whose teaching has a tendency to Judaistic practice in Philadelphia (for comments see Srawley, 1910, 25; Trebilco, 1991, 28).

The number of surviving inscriptions show a sharp decline throughout the Late Antique World (for the decline of epigraphy see Mango, 2008, 144-149), and similarly in Philadelphia. However, two pieces of epigraphic evidence near the city reveal the presence of Jews also in Late Antiquity. A III ${ }^{\text {rd }}$ century A.D. inscription reads: "To the most holy synagogue of the

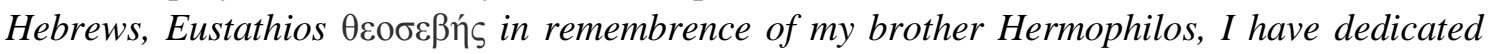
together with my bride (sister-in-law?) Athanasia, the wash basin" ( $\theta \varepsilon \circ \sigma \varepsilon \beta \eta$ ' means "the pious one' see Trebilco, 1991, 162). The other evidence dated tentatively to the IV ${ }^{\text {th }}$ century A.D. is a stele on which a menorah is depicted (Malay, 1994, 125).

There is still some evidence for Jewish communities from cities in the region such as Sardis, Ephesus and Pergamum during the age of Justinian. It seems that despite the restricting codes promulgated, particularly under Theodosius II and Justinian, as well as the campaign of John of Ephesus including some conversion of synagogues into churches in Asia, Caria, Phrygia and Lydia (Harvey, 1990, 99); Jewish communities somehow retained their existence in the cities surrounding Philadelphia, as in many regions in the age of Justinian (for the map [Fig. 2] showing the areas and places of Jewish settlements in the age of Justinian see de Lange, 2005, 412-413).

\section{Christians}

Our knowledge of early Christian history in Philadelphia is clearer than that for the Jewish community. There are some documents suggesting that the early Christian period in Philadelphia dates from when the Christianity began to spread.

One tradition suggests that Paul appointed one of his relatives, Lucius (Romans, 16:21) as Bishop of Philadelphia. However, according to the Apostolic Constitutions, its first Bishop was Demetrius, who was appointed by John (Meinardus, 1974, 80). The more detailed reference comes from the Book of Revelation. The first part of the Revelation consists of the letters addressed to the Seven Churches in Asia. Although it has a lot of metaphors and some of the statements are not sufficiently clear, the message to the angel of the church in Philadelphia (Rev 3:7-13) is quite informative especially as it indicates the early conflicts between Christians and non-Christians in Philadelphia, as well as the significance of the location of the city, indicated earlier (For more detailed comments on the messages see Ramsay, 1904, 401-412; Calder, 1923, 325-327). Philadelphia appears again in the letters, similar to John's, written to the seven churches in Asia Minor probably a couple of decades or less after the date of the Apocalypse. One of the Apostolic Fathers, Ignatius highly commended the Philadelphians and the bishop of the church in The Letter to the Philadelphians. He also emphasized the significance of dependence on the clergy: “...especially if they be at one with the bishop and with the presbyters who are with him, and with the deacons appointed according to the mind of Christ..." (his comments on the disagreements between Christians and non-Christians has already been stated above. For the Epistles of St. Ignatius and comments see Trevett, 1989, 316318).

The subsequent ecclesiastical chronicles rarely mention Philadelphia. In the times of persecution, in Smyrna eleven Philadelphians were martyred with Polycarp, the Bishop of Smyrna, probably between 156 and 167 A.D. (Milner, 1832, 312; Trebilco, 1991, 29).

The controversies especially between the Christian and non-Christian communities that can be partly traced in Philadelphia in the early years of Christianity, continued with the emergence 
of some sects among the Christians during Late Antiquity. One of these movements was Montanism, emerged in Phrygia in the second half of the $\mathrm{II}^{\text {nd }}$ century. In brief, Montanists emphasized the role of the "new prophets" - Montanus and the two women, Priscilla and Maximilla - a stress on asceticism and rejection of marriage, as well as the veneration of Pepouza in Phrygia as the New Jerusalem (Gregory, 1991, 1401). They also elevated virginity and recognized female bishops and presbyters, whether it originated from the Cult of Cybele or from a Christian tradition of Phrygia (for comments on the origins of Montanism see Kaçar, 2002, 42-43).

What Eusebius wrote of the place of emergence of Montanists, Ardabau caused different comments concerning the precise location and the sphere of influence of the movement. Though Philadelphia probably was not the cradle of Montanists, some scholars pointed to some influence, "even a recruiting ground for the Montanists" (Foss, 1976, 33). One of the female leaders that Kaçar (Kaçar, 2002, 43) attributes the origin of the movement to was a Philadelphian, Ammia who lived in the middle of the II $^{\text {nd }}$ century. Besides, a tombstone found in Mendehora, about thirty kilometers east of Sardis and dated to 514-515 witnesses to the existence of a Philadelphian Montanist Bishop (Foss, 1976, 33). Again, the evidence is insufficient, but Philadelphia's proximity to Ardabau or to the second center Pepuza, and the wide spread of the movement in the Empire, suggests the presence of Montanists in the city, whose but Montanist population we can't estimate.

The Montanists' attitudes towards Christianity attracted negative reactions from some church fathers and they have been many times excommunicated (Kaçar, 2002, 50) and regarded as heresy. According to Procopius, the Montanists of Phrygia burned themselves in their churches in the campaign of Justinian against heresies (Procopius, Anekdota, XI;). The successors of the movement are known as late as the early VIII ${ }^{\text {th }}$ century (Starr, 1970, 2) and it is thought to have survived into the IX ${ }^{\text {th }}$ century (Gregory, 1991, 1401).

Another belief among the early Christians deserves a short mention indicating how even little differecences in interpretations caused great controversies. In the $\mathrm{II}^{\text {nd }}$ century, the churches in Asia observed Easter on the day of the Passover, on the $14^{\text {th }}$ day of the moon, thus they were called Quartodecimans (meaning fourteenth) (Sel-Kinran, 2004, 104). Archbishop Nestorius is known even to have commenced a persecution against the Quartodecimans of Asia in 428 at the time also Philadelphia had bishops and a great number of adherents of the Quartodecimans (Foss, 1976, 32). Foss writes "Their abjuration of Heresy at the Council of Ephesus in 431 are preserved..” (Foss, 1976, 32-33).

As in the the case of Lydian cities, epigraphic evidence is quite sparse for the early Christianity in Philadelphia (for early Christian inscriptions in Lydia see Mitchell, 1993, 38). The earliest Christian inscription belongs to the $\mathrm{IV}^{\text {th }}$ or $\mathrm{V}^{\text {th }}$ century. (for the inscription see Calder, 1923, 325; Malay, 1994, 142 for the undated Christian inscriptions from Philadelphia see Malay, 1999, 160-163).

Certain named bishops are known to have represented the Church of Philadelphia at the Councils: at the Ecumenical Council of Nicaea in 325, Bishop Hetimasius; at the Council of Philippolis in 344, Cyriacus; at the Council of Seleucia in 359, bishop Theodosius; at the Council of Ephesus in 431, Bishop Theophanes (Jonsson, 2005, 385-386; http://www. newadvent.org/cathen/11793a.htm/ 13.4.2014).

\section{Conclusion: The Fate of the Pagans, Jews and Christians}

Philadelphia's location on one of the significant intersection of the network of roads during 
Roman Empire and subsequently enabled the penetration of various religions from different parts of Asia Minor. A historical sequence of these religions can partly be made from the written sources. However, how those who had different beliefs lived together, whether there was tolerance or not, and when some traditions of beliefs declined, we have to confront the fact that the archaeological and written evidence differs from region to region, even sometimes contrasts with each other.

Therefore, the attempt has been made to try to summarize the probable fate of beliefs, their persistence and decline in Philadelphia, based upon the evidence from the city, the neighbouring region, and from different parts of the Empire.

It is evident from archaeological remains that cult traditions in Philadelphia continued to some extent as late as the end of the $\mathrm{III}^{\mathrm{rd}}$ or the beginning of $\mathrm{IV}^{\text {th }}$ century. However, for the fate of the paganism in the following centuries one should rely on evidence from the neighbouring cities and provincies. Paganism generally survived in the Empire as late as the $\mathrm{V}^{\text {th }}$ century and in some regions persisted longer, despite the repetition of anti-pagan edicts (for paganism in Late Antiquity in a regional perspective see Mulryan, 2011, 41-86; for current comments on the fate of Late Antique Paganism, see Lavan, 2011, xix-1vi). Lydia was one of the last strongholds of paganism. Marinus, writing on the life of Proclos (412-485) mentioned that Proclos had left Athens for Lydia where the old pagan rituals still survived. During his one year stay there, he examined the traditions of pagans (Onur, 2013, 51-52). About a century later John, Bishop of Ephesus was commisioned by Justinian with the task of converting non-Christians. On missions in Lydia, Asia, Caria and Phrygia, he claimed to have converted eighty thousand pagans and received goverment aid to found ninetyeight churches and twelve monasteries (Harvey, 1990, 29; Mitchell, 1993b, 118). During this missionary voyage, one of his targets was likely Philadelphia which was renowned for its surviving pagan festivals and temples at that time. Sardis may illuminate the fate of paganism in neighbouring cities. According to a document dated after 539, remaining pagans were banished from the city and one of them was imprisoned in the xenon, hospital (Foss, 1976, 29). One should look for traces of the few pagans outside of the city and this is mostly the case for later periods. This is not to say that all pagan activities were confined to the countryside, or died out; tradition continued more or less (for the Pagan traditions in the Christian Empire see Mulryan, 2011, 70-86). However that this was a large scale persistence can not be said considering the increasing dominant Christian character of the Empire.

The evidence for the Jews in Late Antique Philadelphia is insufficient to demonstrate their persistence or decline nor to what extent they were integrated into the life of the city. Epigraphic evidence often remains fragmentary especially from the $\mathrm{IV}^{\text {th }}$ century A.D. onwards in Anatolia, as in Philadelphia.

While controversies between Jews and Christians are attested as early as the $\mathrm{I}^{\mathrm{st}}$ century A.D. and during Late Antiquity (especially based on the nature of Christ and Jewish traditions, see Kaçar, 2009, 24-26, 34ff), the replacement of the moderate attitudes against the Jews in the Hellenistic and Roman periods with their segregation began gradually through the Christianisation of the Empire at the time of Constantine (for Constantine's plan in Palestine see Irshai, 2012, 27). Afterwards, beginning from Theodosius II, the building of new synagogues were restricted and related attitudes such as interference in ritual activities and forcing to baptism was retained during the $\mathrm{VI}^{\text {th }}$ and $\mathrm{VII}^{\text {th }}$ centuries (for the Laws until Justinian see Irshai, de Lange, 2005, 408; 2012, 41, 57; for after Justinian see Starr, 1970, 1-10; Herrin, 2008, 243244). 
The laws show an obvious discrimination, however, the fate of the Jews is partly persistence, unlike Pagans, is known from their ongoing population during Late Antiquity and in subsequent times. In the age of Justinian, there were many Jewish communities including in Asia and Lydia; Jews had reserved seats in the odeum, probably in the $\mathrm{VI}^{\text {th }}$ century in Aphrodisias (Trebilco, 1991, 175); despite the prohibition, during the $\mathrm{V}^{\text {th }}$ and $\mathrm{VI}^{\text {th }}$ century some synagogues are known to have been repaired, built and even enlarged (Foss, 1976, 30; de Lange, 2005, 406). About half a century later the campaign of John of Ephesus including some conversion of synagogues into churches in Asia, Caria, Phrygia and in Lydia, where there were still Jews who repaired their Synagogue in Sardis (Foss, 1976, 42).

Christianity in Philadelphia from its very early years into Late Antiquity was problematic but it ultimately triumphed, as was likewise in many parts of Asia Minor. The controversies between the Jewish and Gentile Christians in the late $\mathrm{I}^{\text {st }}$ and $\mathrm{II}^{\mathrm{nd}}$ century A.D., continued even in the dominant centuries of Christianity. While the Empire left behind some troublesome days for the Christians, it still dealt with the never ending debates of the ecclesiastics. Some Philadelphian Bishops became involved in such debates in the councils of the Empire and sometimes the City's Christians such as the Montanists and Quartodecimans were regarded as heretics. However, despite all this, the Empire gradually manifested its Christian domination over all religions with its various politics of Christianisation. When one surveys the picture by the end of Late Antiquity, can probably see most of the cities in Anatolia covered in a Christian identity with its administration and buildings rather than preceding traditions. We would likely find the same character in Philadelphia, if most of the remains weren't underneath today's city.

\section{REFERENCES}

Akdeniz, E. (2010). "Manisa Yöresindeki Prehistorik- Protohistorik Buluntu Merkezlerinin Dönemsel ve Coğrafi Dağılımları”. Akdeniz-Sanat Dergisi, III/6, 1- 27, Ankara.

Baz, F. (1998). Roma Imparator Kültü. Master's Thesis, İstanbul Marmara Üniversitesi, Sosyal Bilimler Enstitüsü, Tarih Anabilim Dalı, Eskiçağ Tarihi Bilim Dalı.

Blake, C., \& Edmonds G. (1982). Biblical Sites in Turkey. İstanbul.

Burrell, B. (2004). Neokoroi Greek Cities and Roman Emperors. Boston: Brill.

Calder, W. M. (1923). "Philadelphia and Montanism”. Bulletin of the John Rylands Library, 7, 309- 354. Source: https://www.escholar.manchester.ac.uk/uk-ac-man-scw:1m1129.

De Lange, N. (2005). “Jews in the Age of Justinian”. The Cambridge Companion to the Age of Justinian, 401- 426. New York: Cambridge University Press.

Doğan, C. (2010). Philadelphia Sikkeleri. Master's Thesis, Aydın Adnan Menderes Üniversitesi, Sosyal Bilimler Enstitüsü.

Foss, C. (1976). Byzantine and Turkish Sardis. Harvard University Press.

Foss, C. (1991). "Philadelphia”. Dictionary of Byzantium. Vol. III, 1648. Oxford: Oxford University Press.

Gregory, T. E. (1991). “Montanism”. Dictionary of Byzantium. Vol. II, 1401. Oxford: Oxford University Press.

Harvey, A. S. (1990). Asceticism and Society in Crisis: John of Ephesus and the Life of the Eastern Saints. Berkeley: University of California Press.

Herrin, J. (2008). Byzantium: A Surprising Life of a Medieval Empire. London: Penguin Books.

Irshai, O. (2012). "Confronting a Christian Empire: Jewish Life and Culture in the World of Early Byzantium”. Jews in Byzantium: Dialectics of Minority and Majority Cultures, 17- 64. Leiden, Boston: Brill.

Jonsson, J. (2005). The Clash of Ideologies. Xulon Press. 
Kaçar, T. (2002). "Montanizm: Erken Kilise'de Çatışan Gelenekler”. Tarih İncelemeleri Dergisi, Vol. XVII, no. 1, 39-59.

Kaçar, T. (2009). Geç Antikçağ'da Hıristiyanlık. İstanbul: Arkeoloji ve Sanat Yayınları.

Lavan, L. (2011). "Introduction: The end of the Temples: Towards a New Narrative?”. The Archaeology of Late Antique 'Paganism', xv- 1xiv. Leiden, Boston: Brill.

Malay, H. (1985). "The Sanctuary of Meter Phileis near Philadelphia”. Epigraphica Anatolica, 6, 111126. Bonn.

Malay, H. (1994). Greek and Latin Inscriptions in the Manisa Museum. Wien.

Malay, H. (1999). Researches in Lydia, Mysia and Aiolis. Wien.

Mango, C. (2008). “Epigraphy”. The Oxford Handbook of Byzantine Studies, 144-149. New York: Oxford University Press.

Meinardus, O. F. A. (1974). “The Christian Remains of Seven Churches of the Apocalypse”. The Biblical Archaeologist, vol. 37, 69- 82.

Meriç, R. (1986). “1985 Yılı Alaşehir Kazı Çalışmaları”. VIII. Kazı Sonuçları Toplantısı, II, 259- 271, Ankara.

Meriç, R. (1988). “1987 Yılı Alaşehir Kazısı”. X. Kazı Sonuçları Toplantısı, I, 157- 170. Ankara.

Meriç, R. (1992). "1990 Yılı Alaşehir Kazısı”. XIII. Kazı Sonuçları Toplantısı, I, 227- 235. Ankara.

Meriç, R. (1993). “1991 Yılı Alaşehir Kazısı”. XIV. Kazı Sonuçları Toplantısı, II, 355- 363. Ankara.

Meriç, R.-Nolle, J. (1985). "Neue Inschriften aus der Umgebung von Philadelphia in Lydien: Badınca". Epigraphica Anatolica, 5, 19-26. Bonn.

Milner, T. (1832). History of the Seven Churches of Asia. London.

Mitchell, S. (1993a). Anatolia: Land, Men and Gods in Asia Minor, Vol. I: The Celts in Anatolia and the Impact of Roman Rule. Oxford: Clarendon Press.

Mitchell, S. (1993b). Anatolia: Land, Men and Gods in Asia Minor, Vol. II: The Rise of the Church. Oxford: Clarendon Press.

Mulryan, M. (2011). “Paganism' in Late Antiquity: Regional Studies and Material Culture”. The Archaeology of Late Antique 'Paganism', 41- 86. Leiden, Boston: Brill.

Onur, F. (2013). Ioannes Lydos ve Peri Arkhon. İstanbul: Arkeoloji ve Sanat.

Ramsay, W. M. (1904). The Letters to the Seven Churches of Asia. London.

Sel, S., \& Kınran, L. (trans.) (2004). Hiristiyanlık Tarihi. İstanbul: Yeni Yaşam Yayınları.

Srawley, J. H. (1910). The Epistles of Saint Ignatius. Vol. I. London. Society for Promoting Christian Knowledge.

Starr, J. (1970). The Jews in the Byzantine Empire (641- 1204). New York. Burt Franklin.

Thonemann, P. (2011). The Meander Valley: A Historical Geography from Antiquity to Byzantium. Cambridge: Cambridge University Press.

Trebilco, P. (1991). Jewish Communities in Asia Minor. Cambridge: Cambridge University Press.

Trevett, C. (1989). “Apocalypse, Ignatius, Montanism: Seeking the Seeds”. Vigiliae Christianae, Vol. 43, no. 4.

Umar, B. (2001). Lydia. İstanbul: İnkılap Kitabevi.

Zanten, D. V. (1975). "The City Walls". A Survey of Sardis and the Major Monuments outside the City Walls, 35- 49. London. Harvard University Press.

Zosimus (A Translation with commentary by Ronald T. Ridley) (1990). New History. Canberra: Australian National University. 


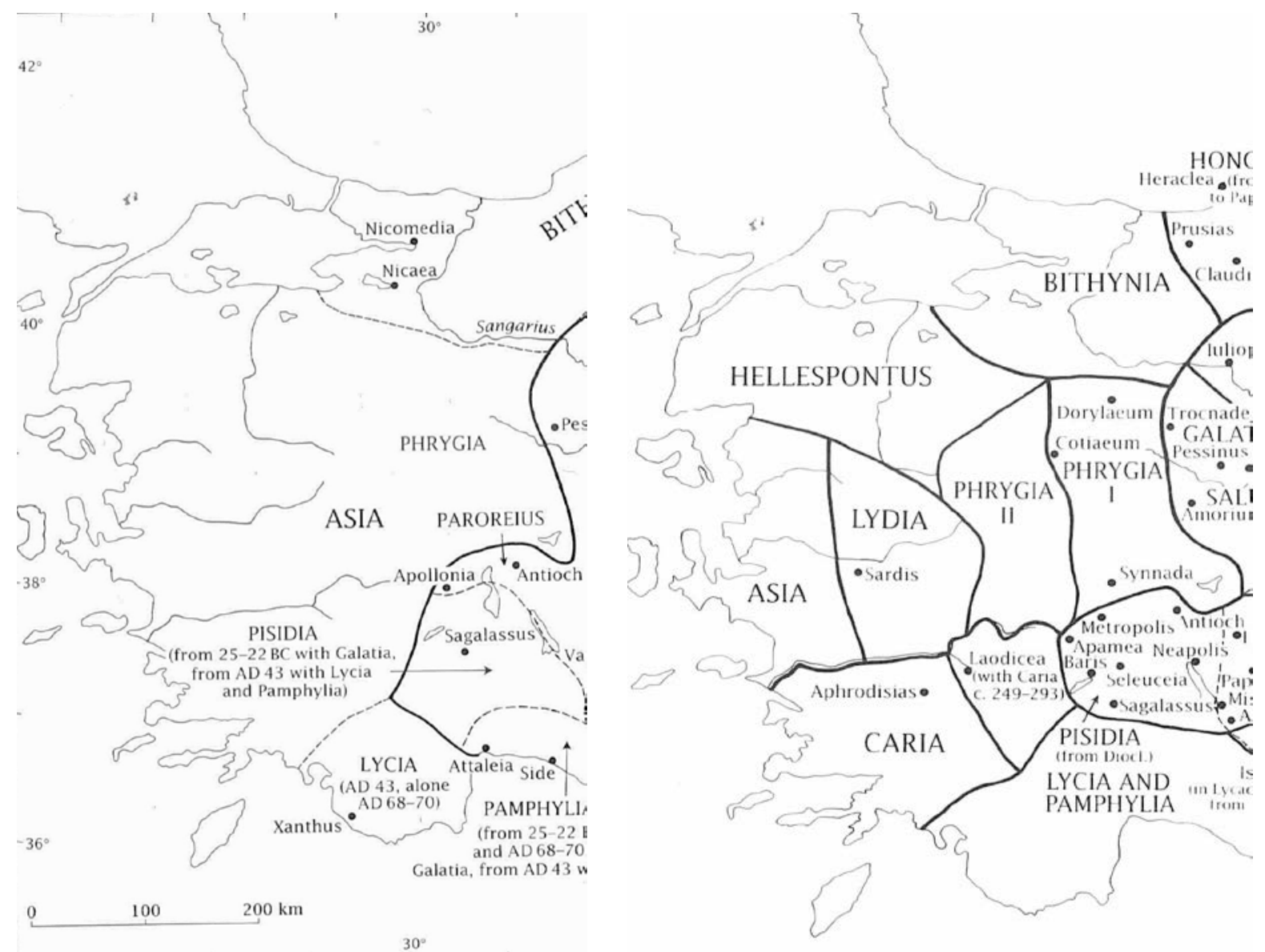

Fig. 1. Provincial boundaries, detail: on the left from 25 B.C. to A.D. 235; on the right in Late Antiquity (Mitchell, 1993b, 156, 162).

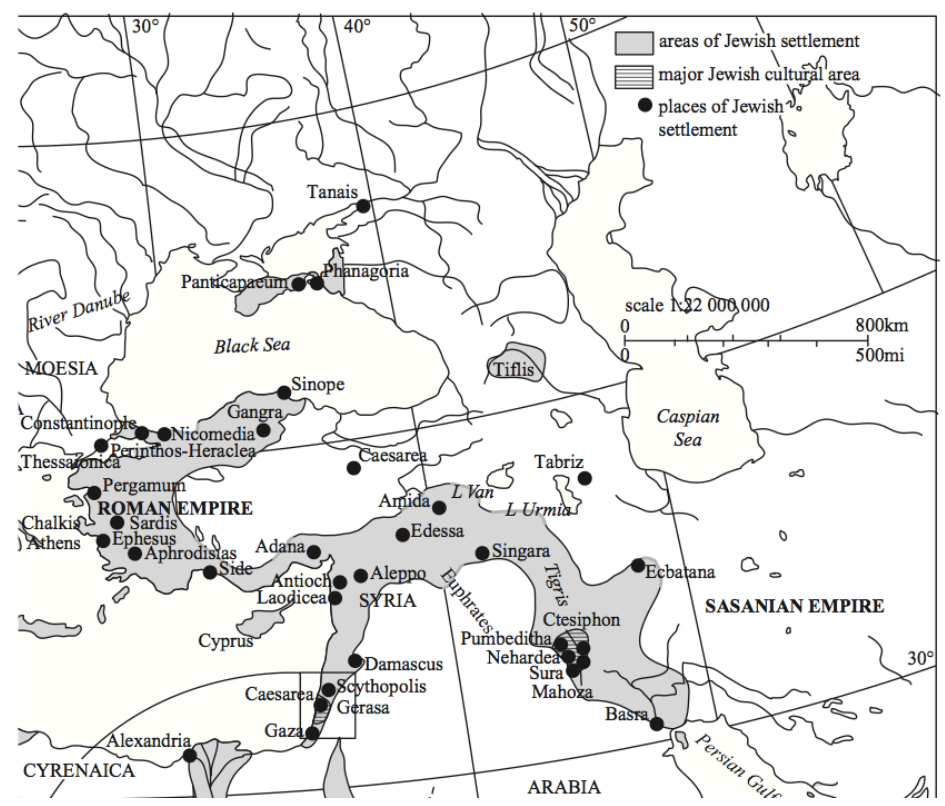

Fig. 2. Jews in the age of Justinian, detail (de Lange, 2005, 413). 
